\title{
Employee Turnover and Job Satisfaction: A synthesis of Factors influencing employee turnover in Institutions of Higher Learning in Ghana
}

Alhassan Abdul Mumin ( $\sim$ proffalhassan@yahoo.com )

university for development studies https://orcid.org/0000-0002-6944-1301

Adams Sulemana Achanso

university for development studies

Musah Ibrahim Mordzeh-Ekpampo

university for development studies

BismarkYeboah Boasu

Simon DiengoDombo University of Business and Integrated Development Studies

David Dei

university for development studies

Research Article

Keywords: Job satisfaction, employee turnover, higher institution

Posted Date: September 13th, 2021

DOl: https://doi.org/10.21203/rs.3.rs-901342/v1

License: (c) (1) This work is licensed under a Creative Commons Attribution 4.0 International License.

Read Full License 


\section{Abstract}

Turnover among teaching staff in our universities are mostly due to dissatisfaction with their jobs. Employee job satisfaction is of utmost importance to stimulating and sustaining the interest of the individual in order to prevent employee turnover. There are many factors influencing employee job satisfaction and preventing employee turnover. Factors such as salary, working conditions, cordial relationship with colleagues at work, opportunities for job progression among several other factors. The objective of this paper was to explore the extent to which these factors, affect employee job satisfaction and prevent turnover among lecturers in the University for Development Studies using the cross-sectional design and quantitative approach of data collection. Survey questionnaires were employed as data collection instruments to elicit information from 287 lecturers recruited from the University for Development Studies within the Tamale Metropolis. Multiple regression was used to establish the effect factors influencing job satisfaction had on employee turnover. Major findings from the study alluded to the fact that salary, working conditions, working environments, carrier advancement, relationship with coworkers have significant correlation with job satisfaction and employee turnover of lecturers in this institution. On account of these findings, this paper suggests yearly salary adjustments, creates a conducive working environment for lecturers, improve upon infrastructural facilities and facilitates carrier advancement issues for lecturers so as to prevent them from exiting the institution.

\subsection{Introduction}

Turnover in higher institutions of learning are becoming a challenge and require certain level of attention. Academic institutions are equipped with professionals who are entrusted with the duty of building human capacity for future generations. The services academicians render to their institutions are irreplaceable and therefore every effort must be made to retain them in their place of work. Furthermore, the research output of our higher institutions of learning will suffer tremendously without the services of academicians as they represent backbone and the brand image of our Universities (Robyn and Du Preez, 2013). In the opinion of Yin-Fah et al (2010), the canker of high rate turnover of experts in institutions globally, is a major threat to the sustenance of organisations.

Many scholarly researches have been conducted to explore factors determining the number of staff who leave their jobs in the service industry, the health area, manufacturing sector, banking sector, the telecom sector and other institutions. For instance, Akeyo and Wezel (2017) conducted a study on how salary and its related issues can lead to some staff switching jobs in the Humanitarian sector using employees of various non-governmental organisations (NGOs). The study found that remuneration was a predicator of staff turnover and recommended that stakeholders employ strategies to control employee turnover in their institutions.

Bilau et al (2015) conducted a research to examine the effect of people moving from one job to the other, had on certain categories of industries by adopting the literature review approach. The study concluded that salary, fringe benefits, lack of financial management and substandard wages are the factors causing 
people to change jobs in organisations that cannot employ many workers. Shah and Beh (2016) investigated the impact of motivation enhanced practices on turnover intentions among hotel managers in Kuala Lumpur. The study distributed 560 questionnaires to elicit response from study participants. It was found out that motivation enhancing practiced (salary, opportunities for job progression, job security among others) had significant relationship with employee turnover intentions.

Jumah and Sulo (2014) also used Herzberg's two-factor theory to examine the extent to which job assignment can affect employee turnover in 24 motels in the City of Kisumu. Their study revealed that job assignment had a significant influence on employee turnover $(p=.005)$. Notwithstanding these evidences, Okwuraiwe et al (2018)undertook a study to find out the effect of sales force turnover on the corporate image of some selected organisations in Anambra State using 246 sample size. The result of the study indicated that high sales turnover, customer's impressions and long-time retention of sales force had some level of effect on the company's brand in Anambra States. Based on these outcomes, the study suggetsts that marketing organisations in Anambra state should put more effort to attend to the needs of their employees so as to encourage them to work hard.

There is, however, few scholarly research on factors affecting employee turnover among lecturers in institutions of higher learning especially in Ghana resulting in scanty information on the subject. Moreover, only few of these studies cited have adopted the cross-sectional design and the quantitative approach to analyse the correlation between factors influencing employee turnover and turnover in higher institutions of learning. In order to address these knowledge and methodological gaps identified in previous research works, this study was undertaken so as to add to the existing body of impeccable knowledge. The objective of this study, therefore, was to identify factors influencing employee turnover among lecturers in the University for Development Studies in the Northern Region of Ghana. The study therefore, hypothesised that:

$\mathrm{H}_{1}$ : the relationship between respondents' level of job satisfaction and turnover intention is statistically significant

$\mathrm{H}_{1}$ : the relationship between factors influencing turnover intention and turnover is statistically significant

\subsection{Literature Review}

\subsection{Employee Turnover}

Turkson (1997) defines labour turnover as the measurement of workers leaving a particular industry and the people succeeding them. Sherman et al, (1988) on their part noted that, employees' turnover is how people change their jobs from one organization to the other. They observed that management should not only be concerned with determining the causes of turnover in its organization, but also examine findings from other organizations in the sector and type of work that will provide a basis for comparison. 


\subsection{Factors affecting employee turnover}

According to Bureau of National Affairs, Inc. cited in Sharman et al, (1988; Turkson, 1997), unattractive working condition, unattractive salary, no proper supervision, delay in promotion, lack of housing facilities, lack of welfare issues and improper work ethics as some of the reasons many staffs had to abandon their work in many institutions and search for another.

Chimanikire et al (2007) carried out a study to investigate the causes of job satisfaction among teaching staff in institutions of higher learning in Zimbabwe using eighty (80) participants. The results show among other factors that, pay and gratuities, absence of banking auto and housing facilities and increasing load of work had effect on workers turnover. They realised that the rate of turnover goes down anytime there are pay increase. The researchers, therefore, advocated for the rolling out of policies like welfare and motivations for workers which could reduce the number of staff exiting the academia in Zimbabwe.

Kipkebut (2010) did some work in some universities in Kenya and realised that people working in the tertiary institutions were not excited about their condition of service, training and human capacity development. Similarly, Kamau and Mberia (2012) collected secondary data from 1999-2010 journals and reviewed them. They found out that pay related factors were some of the factors influencing turnover in public universities. Sajid and Shaheen (2013) researched into factors causing high and low motivational levels among teaching staff in a university in India. Teaching environment (82.9\%) and workload were found to be factors responsible for high motivation among the staff.

Hee and Ann (2019) carried a research to investigate factors affecting employee turnover in a food industry in Malaysia. The study recommended that, high pay and incentives, work-life balance, work stress and job satisfaction are the factors influencing employee turnover. Kartono and Hilmiana (2018) studied how emotional intelligence may result in employee contemplating turnover intention using quantitative method and a sample size of 233 employees from PD, BPR Rural Banks in West Java province. The research found that social and personal competencies positively affect employees desire to quit characterises by the behaviours of deciding to search for new job. The result also suggested that employee going through emotional exhaustion have the high tendency to quit and look for new job opportunities.

Oginni and Omoyele (2018) conducted a study in Nigeria to explore how labour turnover affect productivity in the manufacturing sector using the cable industry as a pilot study. The study used a sample of 420 employees with $65 \%$ response rate. The results indicated that employees' decision to leave and join other organisation is a recurring issue at the work place. This scenario also depends on many driving forces such as work design, emotional trauma, location and organisational politics emanating from organisational policies. The results indicated again that work factors, environmental issues, personal factors as well as organisational policies are the main aspects of labour turnover which affect organisational productivity. 


\subsection{Materials And Methods \\ 3.1 Study Design}

The cross-sectional design with the quantitative approach was used to elicit data from the study participants. The quantitative research approach is appropriate for studies that sought to gather data for a long period. Sale (2002) in examining the merits of this method emphasised that it allows the researcher to examine a phenomenon without influencing it or being influenced by it and vice versa. In the same vein, Golafshani (2003) added his voice and observed that quantitative research enables the researcher the room to interact with the problem under investigation.

\subsection{Sampling design and method of data collection}

The population under consideration in this research were lecturers from the University for Development Studies in the Tamale Metropolis. The study used the multi-stage sampling technique. In the first place, purposive sampling technique was used in selecting the University for Development Studies because it is the only traditional University in Tamale, the capital of the Northern Region of Ghana and falls under the remit of the Ghana Tertiary Education Commission (G-TEC), (a body mandated to be in-charge of all tertiary institutions in Ghana). Secondly, the study recruited 287 lecturers using the simple random sampling technique. The sample size was determined using formula provided by Saunders et al (2009) with a margin of error estimated at $8 \%$. The mathematical formula used in the determination of the sample size is as follows:

$\mathrm{n}=\mathrm{N}$

$1+N(a)^{2}$

Where,

$\mathrm{n}=$ sample

$\mathrm{N}=$ sample population

$a=$ margin of error estimated at $8 \%$

\subsection{Data Collection Tools}

Questionnaires were administered to all respondents at convenient places. The content has to do with the subject matter of the study that is employee turnover and factors influencing people to quit their job. Questions were asked on salaries, job progression, bonuses, allowances condition of service, working environment, relationship with co-workers, conflict management, workload, work hours and training programmes. The first phase of the questionnaire dealt with questions on socio-demographic characteristics of participants: sex, rank and monthly income. The second phase dealt with questions on respondents' level of job satisfaction. There were five items in this section and respondents were 
supposed to rate them using five point Likert scale ranging from 1-satisfied, 2-highly satisfied, 3-niether satisfied nor dissatisfied, 4-dissatisfied and 5-highly dissatisfied. The third phase dealt with respondents' turnover intention levels. There were three items in this section and respondents were to rate them on a five point Likert scale ranging from 1-agree, 2-strongky agree, neither agree nor disagree,4-disagree and 5strongly disagree.

English language was used as the medium of communication by virtue of the fact that it is the only official language used in teaching and respondents could communicate very well with it Ethical approval was sought for and all rules and regulations to ensure confidentiality of information were duly followed. Written consent was given to participants to fill and sign them willingly after which data collection began.

\subsection{Measurement of variables}

Employee turnover was measured according to Turkson (1997)criteria that is the decision of employees to exit their institutions is contingent on factors such as poor working conditions, unequal pay, absence of proper supervision, lack of job progression, lack of shelter among other factors. These items were therefore, taken into consideration in preparing the instruments of data collection. Questions generated from the literature review on causes of employee turnover were asked and a Likert scale ranging from 1agree to 5-strongly disagree was developed to elicit response from the participants.

\subsection{Reliability and Validity of Data}

Reliability is the consistency of research instruments in terms of providing credible results (Seidu, 2011) while validity is when a research instrument measures what it is intended to measure (Cohen, Manin and Morrison, 2003). Reliability and validity are vital in any research such as this current research work (Seidu, 2011). The study piloted the questionnaire on 20 lecturers. The result of the pilot test, tested for reliability of the questionnaire using Cronbach's Alpha (a). From the Cronbach's Alpha test, items under each component of the questionnaire had alpha level more than 0.7 , indicating that the questionnaire is reliable. The study employed content validity method to ensure that questionnaire is valid. The study adopted this method because it gives expert view about whether or not the instruments measured what it was supposed to measure. Furthermore, questions were repeated to respondents to check the consistency in their answers. Subsequently, the researchers paid courtesy visits to participants after data collection to reconcile some of the answers provided previously.

\subsection{Data Analysis}

Descriptive statistics were generated from the quantitative data and the result presented in tables after coding. Multiple regression was also used in testing the correlation between factors influencing employee turnover and turnover intentions.

\subsection{Results And Discussions}

\subsection{Demographic Characteristics of Study Participants}


The results of the study revealed that majority of the sampled participants $(77.0 \%)$ were males while $(23.0 \%)$ were females. The findings of the study also showed that many of the study respondents were assistant lecturers and earned between $₫ 3500-4500$ monthly. Additionally, it was realised from the study outcome that very few respondents were at the rank of associate and full professors and earned above $₫ 7000$ monthly (Refer to Table 1).

Table 1

Demographic Characteristics of study

Participants

\begin{tabular}{|c|c|c|}
\hline \multicolumn{3}{|l|}{ Frequency Percentages } \\
\hline \multicolumn{3}{|l|}{ Sex } \\
\hline Male & 221 & 77.0 \\
\hline Female & 66 & 23.0 \\
\hline \multicolumn{3}{|l|}{ Academic Rank } \\
\hline Assistant lecturer & 138 & 48.1 \\
\hline Lecturer & 110 & 38.3 \\
\hline Senior Lecturer & 29 & 10.1 \\
\hline Associate professor/Professor & 10 & 3.5 \\
\hline \multicolumn{3}{|l|}{ Monthly Income } \\
\hline$\otimes 3500-4500$ & 138 & 48.1 \\
\hline$\triangle 5000-5500$ & 110 & 38.3 \\
\hline$\nabla 6000-6500$ & 29 & 10.1 \\
\hline$\otimes 7000+$ & 10 & 3.5 \\
\hline Source: Field Survey, 2020 & & \\
\hline
\end{tabular}

\subsection{Respondents' Level of Job Satisfaction}

The study measured respondents level of job satisfaction by providing these statements to be rated by respondents using a Likert scale. The results suggest that majority of respondents were of the opinion that their job gives them sense of security as (39.0\%) and (29.6\%) of respondents agreed and strongly agreed respectively with the statement. Most of the respondents also claim that they do not get high pay from their job (that is $28.9 \%$ were dissatisfied while $40.1 \%$ were strongly dissatisfied) with their monthly income. The results indicate that respondents were highly dissatisfied with their job (Refer to Table 2). 
Table 2

Respondents' Level of Job Satisfaction

\begin{tabular}{|llllll|}
\hline Statements & Dissatisfied & $\begin{array}{l}\text { Highly } \\
\text { Dissatisfied }\end{array}$ & Neutral & satisfied & $\begin{array}{l}\text { Highly } \\
\text { satisfied }\end{array}$ \\
\hline My work gives me sense of security & 56 & 27 & 7 & $\begin{array}{l}112 \\
(39.0 \%)\end{array}$ & $\begin{array}{l}85 \\
(29.6 \%)\end{array}$ \\
& $(19.5 \%)$ & $(9.4 \%)$ & $(2.4 \%)$ & & \\
Am highly paid & 82 & 115 & 21 & 29 & 40 \\
& $(28.9 \%)$ & $(40.1 \%)$ & $(7.3 \%)$ & $(10.1 \%)$ & $(13.9 \%)$ \\
\hline My job satisfying & 111 & 94 & 21 & 34 & 27 \\
& $(38.7 \%)$ & $(32.8 \%)$ & $(7.3 \%)$ & $(11.8 \%)$ & $(9.4 \%)$ \\
\hline My job provides me with sense of & 75 & 69 & 60 & 30 & 53 \\
accomplishment & $(27.2 \%)$ & $(24.0 \%)$ & $(22.0 \%)$ & $(10.5 \%)$ & $(18.5 \%)$ \\
\hline My job is exciting & 55 & 138 & 1 & 60 & 33 \\
& $(19.2 \%)$ & $(48.1 \%)$ & $(3.0 \%)$ & $(20.9 \%)$ & $(11.5 \%)$ \\
\hline My job is stressful & 12 & 36 & 69 & 74 & 96 \\
\hline Source: Field Survey, (2020) $\mathrm{N}=(287)$ & & $(12.5 \%)$ & $(24.0 \%)$ & $(25.8 \%)$ & $(33.4 \%)$ \\
\hline
\end{tabular}

\subsection{Respondents Level of Turnover Intention}

The study sought to find out from the respondents if they had any intention of leaving their jobs by making a statement 'I will be searching for a new job in the next coming days; I sometimes think of exiting my job and I may have to leave lecturing very soon and provided a Likert scale ranging from 1agree to 5 strongly disagree and asking participant to tick appropriately. This result suggests that majority of the respondents $(61.4 \%)$ that is (19.2\% plus $42.2 \%)$ were considering searching for new jobs in the coming days. Most of the respondents also affirm the statement; sometimes I think of exiting my job (agree (27.9\% and strongly agree $36.9 \%$ ). While $23.0 \%$ and $47.4 \%$ confirm the statement; I may have to leave lecturing very soon (See Table 3 ). 
Table 3

Respondents' Level of Turnover Intention

\begin{tabular}{|c|c|c|c|c|c|}
\hline & agree & $\begin{array}{l}\text { Strongly } \\
\text { agree }\end{array}$ & Neutral & Disagree & $\begin{array}{l}\text { Strongly } \\
\text { disagree }\end{array}$ \\
\hline $\begin{array}{l}\text { I will be searching for a new job in the } \\
\text { next coming days }\end{array}$ & $\begin{array}{l}57 \\
(19.2 \%)\end{array}$ & $\begin{array}{l}121 \\
(42.2 \%)\end{array}$ & $\begin{array}{l}35 \\
(12.2 \%)\end{array}$ & $\begin{array}{l}36 \\
(12.5 \%)\end{array}$ & $\begin{array}{l}38 \\
(13.2 \%)\end{array}$ \\
\hline I sometimes think of exiting my job & $\begin{array}{l}80 \\
(27.9 \%)\end{array}$ & $\begin{array}{l}106 \\
(36.9 \%)\end{array}$ & $\begin{array}{l}16 \\
(5.6 \%)\end{array}$ & $\begin{array}{l}46 \\
(16.0 \%)\end{array}$ & $\begin{array}{l}39 \\
(13.6 \%)\end{array}$ \\
\hline I may have to leave lecturing very soon & $\begin{array}{l}66 \\
(23.0 \%)\end{array}$ & $\begin{array}{l}136 \\
(47.4 \%)\end{array}$ & $\begin{array}{l}30 \\
(10.5 \%)\end{array}$ & $\begin{array}{l}27 \\
(9.4 \%)\end{array}$ & $\begin{array}{l}28 \\
(9.8 \%)\end{array}$ \\
\hline
\end{tabular}

The study further sought to find out from respondents what is influencing their intention to leave their jobs by providing factors influencing turnover as reviewed in the literature and provided a Likert scale ranging from 1-agree to 5- strongly disagree and asking respondents to tick appropriately. The result of the descriptive statistics showed that respondents' intention to exit their job was influenced by factors such as income, condition of service, job advancement, conflict with management, training programmes and job security. However, the result also indicated that respondents did not consider factors such as workload, working environment, relationship with co-workers and work hours to determine their decision to leave their job or not (Refer to Table 4) 
Table 4

Reasons for Turnover Intention

\begin{tabular}{|c|c|c|c|c|c|}
\hline & agree & $\begin{array}{l}\text { Strongly } \\
\text { agree }\end{array}$ & Neutral & Disagree & $\begin{array}{l}\text { Strongly } \\
\text { disagree }\end{array}$ \\
\hline Employee turnover & $\begin{array}{l}94 \\
(32.8 \%)\end{array}$ & $91(31.7 \%)$ & $\begin{array}{l}17 \\
(5.9 \%)\end{array}$ & $\begin{array}{l}65 \\
(22.6 \%)\end{array}$ & $\begin{array}{l}20 \\
(7.0 \%)\end{array}$ \\
\hline income & $\begin{array}{l}126 \\
(43.9 \%)\end{array}$ & $68(23.7 \%)$ & $\begin{array}{l}20 \\
(7.0 \%)\end{array}$ & $\begin{array}{l}34 \\
(11.8 \%)\end{array}$ & $39(13.6 \%)$ \\
\hline Condition of service & $\begin{array}{l}90 \\
(31.4 \%)\end{array}$ & $\begin{array}{l}111 \\
(38.7 \%)\end{array}$ & $\begin{array}{l}18 \\
(6.3 \%)\end{array}$ & $\begin{array}{l}49 \\
(17.1 \%)\end{array}$ & $\begin{array}{l}19 \\
(6.6 \%)\end{array}$ \\
\hline Working environment & $\begin{array}{l}95 \\
(33.1 \%)\end{array}$ & $90(31.4 \%)$ & $\begin{array}{l}24 \\
(8.4 \%)\end{array}$ & $\begin{array}{l}40 \\
(13.9 \%)\end{array}$ & $38(13.2 \%)$ \\
\hline $\begin{array}{l}\text { Relationship with co- } \\
\text { workers }\end{array}$ & $\begin{array}{l}102 \\
(35.5 \%)\end{array}$ & $73(25.4 \%)$ & $\begin{array}{l}19 \\
(6.6 \%)\end{array}$ & $\begin{array}{l}71 \\
(24.7 \%)\end{array}$ & $\begin{array}{l}22 \\
(7.7 \%)\end{array}$ \\
\hline Work load & $\begin{array}{l}28 \\
(9.8 \%)\end{array}$ & $50(17.4 \%)$ & $\begin{array}{l}19 \\
(6.6 \%)\end{array}$ & $\begin{array}{l}82 \\
(28.6 \%)\end{array}$ & $\begin{array}{l}108 \\
(37.6 \%)\end{array}$ \\
\hline Work hours & $\begin{array}{l}31 \\
(10.8 \%)\end{array}$ & $50(17.4 \%)$ & $\begin{array}{l}27 \\
(9.4 \%)\end{array}$ & $\begin{array}{l}91 \\
(31.7 \%)\end{array}$ & $88(30.7 \%)$ \\
\hline Job advancement & $\begin{array}{l}94 \\
(32.8 \%)\end{array}$ & $89(31.0 \%)$ & $\begin{array}{l}23 \\
(8.0 \%)\end{array}$ & $\begin{array}{l}49 \\
(17.1 \%)\end{array}$ & $32(11.1 \%)$ \\
\hline Conflict with management & $\begin{array}{l}88 \\
(30.7 \%)\end{array}$ & $84(29.3 \%)$ & $\begin{array}{l}20 \\
(7.0 \%)\end{array}$ & $\begin{array}{l}43 \\
(15.0 \%)\end{array}$ & $52(18.1 \%)$ \\
\hline Job security & $\begin{array}{l}93 \\
(32.4 \%)\end{array}$ & $75(26.1 \%)$ & $\begin{array}{l}13 \\
(4.5 \%)\end{array}$ & $\begin{array}{l}40 \\
(13.9 \%)\end{array}$ & $66(23.0 \%)$ \\
\hline Training programs & $\begin{array}{l}119 \\
(41.5 \%)\end{array}$ & $\begin{array}{l}16 \\
(5.6 \%)\end{array}$ & $\begin{array}{l}39 \\
(13.6 \%)\end{array}$ & $\begin{array}{l}39 \\
(13.6 \%)\end{array}$ & $74(25.8 \%)$ \\
\hline
\end{tabular}

\subsection{Testing of hypotheses}

$\mathrm{H}_{1}$ : The relationship between respondents' level of job satisfaction and turnover intention is statistically significant 
$\mathrm{H}_{2}$ : the relationship between factors influencing (turnover intention) and turnover is statistically significant

The results of the regression model indicate that the factors statistically significantly predict turnover intention among respondents. (Refer to Table 5).

Table 5

Analysis of variance (ANOVA)

\begin{tabular}{|llllll|}
\hline Model & Sum of squares & df & Mean square & F & Sig. \\
\hline Regression & 428.231 & 10 & 42.8823 & 150.991 & $.000^{\mathrm{b}}$ \\
1 ....Residual & 78.278 & 276 & .284 & & \\
Total & 506.506 & 287 & & & \\
\hline & & & & & \\
\hline
\end{tabular}

a. Dependent variable: you will leave your job

b. Predicators: (constant), no training program for employees will make you leave, job security will make you leave, condition of service will influence you to move, working environment will make you exit, job advancement can make you leave, relationship with co-workers will make you leave, income will influence your decision to leave, work hours will make you leave, work load will make you leave, conflict with management will make you leave.

The study proceeded further to use multiple regression model to predict the impact of each of the factors on turnover intention: income, condition of service, job advancement, job security, conflict with management, relationship with co-workers, working environment, work hours, workload and training programmes on respondents' intention to leave. The variables, with the exception of relationship with coworkers, working environment, work hours and workload, statistically significantly predict respondents' intention to leave their jobs. In fact the result indicated that income strongly predicted respondents' intention to leave more than all the other variables. This implies that among all the factors, income as in (salary, allowances, bonuses and gratuity) has a greater impact more than the others in influencing respondents' decision to leave their jobs. This result also implies that relationship with co-workers, working environment, work hours and workload did not predict significantly respondents' intention to leave (Refer to Table 6). 
Table 6

Coefficients $^{a}$

\begin{tabular}{|c|c|c|c|c|c|}
\hline \multirow[t]{3}{*}{ Model } & \multicolumn{2}{|c|}{ Unstandardised coefficients } & \multirow{3}{*}{$\begin{array}{l}\text { Standardised } \\
\text { coefficients } \\
\text { Beta }\end{array}$} & \multirow[t]{3}{*}{$\mathbf{t}$} & \multirow[t]{3}{*}{ Sig. } \\
\hline & B & Std, & & & \\
\hline & & Error & & & \\
\hline 1 (constant) & 1.661 & .503 & & 3.304 & .001 \\
\hline Condition of service & .126 & .047 & .138 & 2.653 & .008 \\
\hline workload & .046 & .045 & .043 & 1.013 & .312 \\
\hline Working environment & _.010 & .040 & $\ldots .011$ & .251 & .802 \\
\hline Relationship with co-workers & _.063 & .044 & _.066 & -1.428 & .154 \\
\hline income & _.209 & .056 & -218 & _3.746 & .000 \\
\hline Work hours & .023 & .053 & .024 & .445 & .657 \\
\hline Job advancement & .144 & .049 & .149 & 2.902 & .004 \\
\hline Conflict with management & .197 & .066 & .221 & 2.966 & .003 \\
\hline Job security & .214 & .077 & .256 & 2.797 & .006 \\
\hline Training programs & _.084 & .029 & -.106 & $\_2.878$ & .004 \\
\hline
\end{tabular}

\subsection{Discussion of the Results}

The essence of this piece of research was to examine the extent to which factors such as salary, condition of service, academic promotion and several other factors may affect employee job satisfaction and prevent turnover among lecturers in the University for Development Studies in Tamale, Ghana, West Africa. Findings from the study indicate that majority of the staff of the university were earning between §3500-4500 monthly which according to the respondents were woefully inadequate.

The study findings further revealed that among all the factors affecting their level of satisfaction and turnover intention, salary and its associated gratuities and emoluments greatly influenced participants' decision to change jobs. Consequently, the results revealed that most of the staff were not satisfied with their jobs and will, therefore, opt for an alternative.

These study findings even though carried out in the year 2020 but still reflect what is currently happening in Ghana among lecturers in all the sixteen (16) public universities spearheaded by their parent organisation that is the university teachers' association of Ghana (UTAG). The association embarked on 
strike on 2nd of August, 2021 to press home for an improved condition of service. The association claims that their condition of service is the worst compared with what other lecturers from other public universities within the sub-region are earnings. The association indicated that the basic salary of a lecturer in Ghana as at now is $₫ 3,600$ ie 600 dollars which is not deserving of a lecturer in the public university.

This result is consistent with findings of Akeyo and Wezel (2017), Bilau et al (2015), Shah and Beh (2016) whose findings suggest that salary and good condition of service are the most important factors influencing job satisfaction and turnover. Contrary, the findings of the study does not agree with findings from Sajid and Shaheen (2013), Kartono and Hilmiana (2018) and Oginni and Omoyele (2018) whose findings indicated that emotional intelligence and environmental conditions are the major factors determining job satisfaction and turnover among employees in the tertiary institutions.

\subsection{Conclusion and Policy Recommendations}

The study was conducted to examine factors influencing employee turnover intention among lectures in the institutions of higher learning. The objective was to examine the relationship between job satisfaction and turnover intention and secondly to investigate factors determining turnover intention using the crosssectional design and the quantitative approach. The study findings suggest that the relationship between job satisfaction and turnover intention is statistically significant. Secondly, there was also an association between factors influencing turnover intention and turnover. These outcomes therefore, justify the hypotheses guiding the study. The study recommends that strategies must be adopted to prevent the exodus of lecturers from our higher institutions of learning.

\section{Declarations}

\section{Consent for Publication}

All authors gave their consent for this article to be submitted for publication in this journal

\section{Availability of data and materials}

The ethical issues were seriously taken into consideration in the course of conducting this research. Participants were provided with consent form to fill voluntarily and anybody who decided not to be part of the study was not coerced to do so. Anonymity and confidentiality of information given by participants was also duly ensured. Therefore, data sharing for this article is not applicable.

\section{Competing interest}

Authors declare no competing interest

\section{Funding}

Authors did not receive any funding to undertake this study. 


\section{Authors' contribution}

The work was solely done by the corresponding author but all other authors read, edited and approved the final manuscript.

\section{Section C}

\section{Acknowledgement}

Authors recognise the contribution of all participants in the selected tertiary institutions who provided responses to all the questions during the data collection process. The authors also acknowledged all scholars who research works provided the basis for literature review for this study.

\section{Authors' Information}

Alhassan Abdul Mumin

Position: Lecturer

Department of Community Development)

Faculty of Sustainable Development

University for Development Studies, Box TL1350, Tamale, N/R Ghana

e-mail: proffalhassan@yahoo.com

Tel: +233243689543

Musah Ibrahim Mordzeh-Ekpampo

Position: Lecturer

Department of Planning and Land Administration

Faculty of Sustainable Development

University for Development Studies, Box TL1350, Tamale, N/R Ghana

Email: ekpampo@yahoo.com

Tel: +233243288556

BismarkYeboah Boasu

Position: Lecturer 
Department of Geography

Simon DiengoDombo University of Business and Integrated Development Studies, Wa, UW/R Ghana

Email: byboasu@ubids.edu.gh

Tel: +233244974476

David Dei

Position: Assistant Lecturer

Department of Management and policy Studies

Faculty of Sustainable Development

University for Development Studies, Box TL1350, Tamale, N/R Ghana

Email: deidave77@yahoo.com

Tel: +233246229843

\section{Conflict of Interest}

Authors declare no conflict of interest

\section{References}

Akeyo, M. and Wezel, D.P. (2017).Factors Influencing Staff Turnover in Logistics Management.American Journal of Economics.1, (1), pp. 79-94.

Bilau, A., A., Witt, E. and Lill, I, (2015).A framework for managing post-disaster housing reconstruction.Procedia Economics and Finance21 (2015) 313-320

Chimanikire1, P., Mutandwa2, E., Gadzirayi3, C., T., Muzondo, N., and Mutandwa, B. (2007). Factors affecting job satisfaction among academic professionals in tertiary institutions in Zimbabwe.African Journal of Business Management vol. 1(6) pp. 166-175,

Hee, O., C. and Ann, Y., S. (2019). Factors Influencing Employee Turnover in the Food Manufacturing Industry in Malaysia. International Journal of Academic Research in Business and Social Sciences, 9(1), 482-491.

Jumah, L., and Sulo, T. (2018).Influence of Job Assignment on Employee Turnover in Selected Medium Sized Hotels in Kisumu City.African Journal of Education,Science and Technology, 2(1), pp 39-45

Kamau, U., Mberia, H. (2012). Retention of Staff in Public Universities.Scientific Conference Proceedings 
Kipkebut, D., J. (2010). Human Resource Management Practices and Organizational Commitment in Higher Educational Institutions: A Kenyan Case.Journal of Organizational Behavior. Vol. 9 Issue 1/2, pp 45-70

Kartonoand Hilmiana (2018). Job burnout: A mediation between emotional intelligence and Turnover intention. JurnalBisnisdanManajemen,Volume 19 (2), pp. 109-121

Oginni, B., O. and Omoyele, S., O. (2018). A Study Of Labour Turnover And Organisational Productivity InThe Cable Industry Of Nigeria Manufacturing Sector. Advances in Social Sciences Research JournalVol.5 (.8),pp.294-305.

Okwuraiwe, F. E., Ezenwaka, C., and Chiyem, O. (2018). Sales Force Turnover and Corporate Image of Selected Marketing Organizations in Anambra Stat. International Journal of Academic Research in Accounting, Finance and Management Sciences, vol. 8-13/4758

Robyn"R. du Preez, R (2013). Intention to quit amongst Generation Y academics in higher education.SA Journal of Industrial Psychology.Vol. 39 (1), pp.1106

Sajid1, A., M. and Shaheen, I. (2013).Factors Responsible for High and Low Motivational Level of University Academicians.International Journal of Science and Research. vol. 2 (2), pp. 2319-7064

Shah, S., H., A and Beh, L.(2016). The Impact of Motivation Enhancing Practices and Mediating Role of Talent Engagement on Turnover Intentions: Evidence from Malaysia. International Review of Management and Marketing, 2016, 6(4), 823-835.

Yin-Fah, B., C., SokFoon.Y., Chee-Leong, L. Osman, S. (2010). An Exploratory Study on Turnover Intention among Private Sector Employees.International Journal of Business and Management.Vo; 5 (8), pp. 5764 